University of Nebraska - Lincoln

DigitalCommons@University of Nebraska - Lincoln

USDA National Wildlife Research Center - Staff Publications
U.S. Department of Agriculture: Animal and Plant Health Inspection Service

2010

\title{
Test of Localized Management for Reducing Deer Browsing in Forest Regeneration Areas
}

Brad F. Miller

Arkansas Game and Fish Commission

Tyler A. Campbell

USDA-APHIS-Wildlife Services-National Wildlife Research Center, tcampbell@eastfoundation.net

Ben Laseter

Fish and Wildlife Associates, Incorporated

W. Mark Ford

USDA-APHIS-Wildlife Services, Northeastern Research Station

Karl Miller

University of Georgia, Athens

Follow this and additional works at: https://digitalcommons.unl.edu/icwdm_usdanwrc

Part of the Environmental Sciences Commons

Miller, Brad F.; Campbell, Tyler A.; Laseter, Ben; Ford, W. Mark; and Miller, Karl, "Test of Localized Management for Reducing Deer Browsing in Forest Regeneration Areas" (2010). USDA National Wildlife Research Center - Staff Publications. 963.

https://digitalcommons.unl.edu/icwdm_usdanwrc/963

This Article is brought to you for free and open access by the U.S. Department of Agriculture: Animal and Plant Health Inspection Service at DigitalCommons@University of Nebraska - Lincoln. It has been accepted for inclusion in USDA National Wildlife Research Center - Staff Publications by an authorized administrator of DigitalCommons@University of Nebraska - Lincoln. 


\title{
Test of Localized Management for Reducing Deer Browsing in Forest Regeneration Areas
}

\author{
BRAD F. MILLER, Arkansas Game and Fish Commission, 2 Natural Resources Drive, Little Rock, AR 72205, USA \\ TYLER A. CAMPBELL, United States Department of Agriculture/Animal and Plant Health Inspection Service/Wildlife Services/National Wildlife \\ Research Center-Texas Field Station, Texas AEM University-Kingsville, Kingsville, TX 78363, USA \\ BEN R. LASETER, Fish and Wildlife Associates, Incorporated, P.O. Box 241, Whittier, NC 28789, USA \\ W. MARK FORD, ${ }^{1}$ United States Department of Agriculture Forest Service, Northeastern Research Station, Parsons, WV 26287, USA \\ KARL V. MILLER, ${ }^{2}$ Warnell School of Forestry and Natural Resources, University of Georgia, Athens, GA 30602, USA
}

\begin{abstract}
White-tailed deer (Odocoileus virginianus) browsing in forest regeneration sites can affect current and future stand structure and species composition. Removal of deer social units (localized management) has been proposed as a strategy to alleviate deer overbrowsing in forest systems. We conducted an experimental localized removal in a high-density deer population in the central Appalachians of West Virginia, USA, during winter 2002. We removed 51 deer within a $1.1-\mathrm{km}^{2}$ area that encompassed 2 forest regeneration sites (14 ha). During the summer following removal, we detected decreases in distance from the removal area in 8 of 30 (26.7\%) adult females having pretreatment mean telemetry locations $<2.5 \mathrm{~km}$ from the center of the removal area. We measured browsing rates during the summers of 2001-2004 from forest regeneration sites to examine efficacy of localized management. Browsing rates declined annually in both removal and control areas, due in part to increased timber harvesting on the larger study site, suggesting that increasing forage availability may be more effective at reducing impacts on forest regeneration than localized reductions in deer populations. Three years after the initial removal, we removed an additional 31 deer from the original $1.1-\mathrm{km}^{2}$ removal area. Home range shifts of adjacent deer coupled with the large number of animals collected in the second removal suggests that localized management only produces temporary voids within high-density deer herds. Localized management may not effectively reduce negative impacts of deer in areas of high deer density.
\end{abstract}

KEY WORDS Appalachians, forest regeneration, herbivory, localized management, Odocoileus virginianus, rose-petal hypothesis, West Virginia, white-tailed deer.

The successful restoration of white-tailed deer (Odocoileus virginianus) populations in the eastern United States has resulted in a variety of social and ecological conflicts. Overabundant deer populations can result in deer-vehicle collisions, depredation of agricultural crops, and damage to ornamental plantings (Conover 1997). Excessive browsing also can have negative effects on forested ecosystems (McShea and Rappole 1997a, Côté et al. 2004), particularly in regenerating forests because long-term successional patterns may be altered (Marquis 1981, Horsley and Marquis 1983, McWilliams et al. 1995). Shifts in species composition, reduced stocking, extended rotation lengths, and entire regeneration failures are possible on some sites (Marquis 1974, Tilghman 1989, Horsley et al. 2003).

Although regulated hunting can effectively control deer populations in many situations, managing deer populations at a regional or even county level may not control locally overabundant populations (Waller and Alverson 1997, McShea and Rappole 2000). Additionally, using hunting as a management tool may not be applicable in all situations. Hunter access is often restricted in suburban areas or public parks because of safety concerns or regulatory constraints (Warren 1991, McShea and Rappole 1997b).

\footnotetext{
${ }^{1}$ Present address: Environmental Laboratory, Ecological Resources Branch, United States Army Engineer Research and Development Center, Vicksburg, MS 39180, USA

${ }^{2}$ E-mail: KMILLER@warnell.uga.edu
}

Alternative techniques for controlling deer populations and reducing their negative impacts have been tested but often are cost-prohibitive (e.g., translocation; Beringer et al. 2002), require substantial effort and interval of time before population densities are reduced (e.g., fertility control; Merrill et al. 2006), or may be viewed unfavorably by the public (e.g., sharp-shooting; Stout et al. 1997). As a result natural resource managers must explore novel approaches for reducing impacts of overabundant deer populations.

Recent research investigating the sociobiological characteristics of female deer has warranted its consideration in management efforts. Female social groups are structured as a series of overlapping home ranges centered on a matriarchial female (Hirth 1977, Tierson et al. 1985, Mathews 1989). The theoretical shape of these social units is similar to the petals of a rose, and has been termed the rose-petal hypothesis. This model of social structuring and population expansion has led researchers to question traditional concepts for deer management that often emphasize population reductions on a large geographical area. Accordingly localized management has been proposed as a management tool that exploits the social structuring of deer (Porter et al. 1991, Mathews and Porter 1993, McNulty et al. 1997). This technique involves the surgical removal of a matriarchal social group(s) from a limited geographical area to create a 10-15-year period of reduced deer densities (Porter et al. 1991). Effectiveness of the technique depends on the suitability of the rose-petal hypothesis as a model for population expansion. Specifically, deer populations must 
exhibit low female dispersal, high female survival rates, and high philopatry for localized management to be applicable.

McNulty et al. (1997) conducted an experimental test of the localized management technique on a low density (2-6 deer $/ \mathrm{km}^{2}$ ), migratory, and unhunted deer population in the Adirondack Mountains of New York, USA. In that study, 14 deer were removed from a $1.4-\mathrm{km}^{2}$ area, and no adjacent female deer $(n=9)$ recolonized the area within 2 years of monitoring. A subsequent examination of the same removal area by Oyer and Porter (2004) approximately 6 years postremoval reported reduced deer densities for a period of 5 years. These results suggest that localized management may be a viable technique to prevent overbrowsing by deer in areas where traditional approaches are unsuitable. Possible sites for applying localized management include urban or suburban areas or parks (Porter et al. 1991, 2004; Kilpatrick et al. 2001). Forest regeneration sites located in remote areas where access to the hunting public is difficult or problematic also may benefit from an application of localized management prior to timber harvesting to ensure successful regeneration (Campbell et al. 2004). However, effectiveness of any behavior-based management technique may be limited by the behavioral plasticity of white-tailed deer (Miller 1997, Comer et al. 2005).

Campbell et al. (2004) assessed the feasibility of implementing localized management on a hunted, nonmigratory, and high-density deer herd in the central Appalachian Mountains of West Virginia, USA, and reported that the a priori assumptions of localized management were met and that a test of localized management on the study site would be possible. Our study evaluated the effectiveness of localized management in reducing browsing rates of forest regeneration areas on the site previously evaluated by Campbell et al. (2004).

\section{STUDY AREA}

We conducted our research on the 3,413-ha MeadWestvaco Wildlife and Ecosystem Research Forest (MWWERF) located in Randolph County, West Virginia $\left(38^{\circ} 42^{\prime} \mathrm{N}\right.$, $\left.80^{\circ} 3^{\prime} \mathrm{W}\right)$. The MWWERF was established in 1994 to investigate the relationship between industrial forestry and ecosystem processes. The MWWERF was located in the Unglaciated Allegheny Mountain and Plateau Physiographic province, and topography consisted of plateau-like ridgetops with steep sides and narrow valleys. Elevations ranged from $700 \mathrm{~m}$ to $1,200 \mathrm{~m}$. The climate was moist and cool with mean annual precipitation $>155 \mathrm{~cm}$ (Strausbaugh and Core 1977). Soils of the MWWERF were acidic, welldrained Inceptisols (Schuler et al. 2002).

Forest types on the MWWERF were naturally regenerated second-growth stands established in the early 1900s following extensive area-wide railroad logging (Clarkston 1993). At the time of our study, the forests were managed primarily by even-aged harvesting with an 80-100-year rotation length (Adams 2005). Forest regeneration sites of approximately 15 ha were well-distributed throughout the MWWERF.
The most common overstory cover was Alleghenyhardwood-northern-hardwood forest composed of American beech (Fagus grandifolia), yellow birch (Betula alleghaniensis), sugar maple (Acer saccharum), red maple (A. rubrum), yellow-poplar (Liriodendron tulipifera), and black cherry (Prunus serotina). Cove hardwoods and mixedmesophytic forests composed of yellow-poplar, basswood (Tilia americana), sweet birch (B. lenta), and northern red oak (Quercus rubra) were common at lower elevations. Eastern hemlock (Tsuga canadensis) and red spruce (Picea rubens) comprised a substantial portion of the forest cover on elevations $>1,000 \mathrm{~m}$ and along sheltered riparian zones. A shrub layer and understory groundcover were absent in many areas with the exception of rhododendron (Rhododendron maximum) thickets in upland and riparian areas and thick mats of hay-scented fern (Dennstaedtia punctilobula) in areas where the canopy was interrupted and sunlight reached the forest floor.

Intensive research of the deer population on the MWWERF began in 1999 (Campbell 2003). Deer densities and sex ratios on the MWWERF at the time of our study were estimated at $12-20$ deer $/ \mathrm{km}^{2}$ and $6-18$ adult males:100 adult females, respectively (Langdon 2001). Male deer experienced high annual mortality from hunting, whereas females average $85-90 \%$ annual survival (Campbell et al. 2005). Telemetry data indicated low $(<5.0 \%)$ dispersal of juvenile females (Campbell et al. 2004). Abomasal parasite counts indicated the deer herd was approaching or had reached nutritional carrying capacity (J. R. Fischer, Southeastern Cooperative Wildlife Disease Study, unpublished report).

\section{METHODS}

\section{Deer Capture and Radiotelemetry}

To collect preliminary biological and movement data, we captured 224 deer (51 M and $173 \mathrm{~F}$ ) from January through April during 1999-2001 using Clover traps and rocket-nets baited with whole-kernel corn (Clover 1954, Hawkins et al. 1968). We physically restrained and blindfolded captured animals, then gave them an intramuscular injection of xylazine hydrochloride $\left(100 \mathrm{mg} / \mathrm{mL}\right.$, Cervizine ${ }^{\circledR}$; Wildlife Laboratories, Fort Collins, CO) at a dosage of $2.2 \mathrm{mg} / \mathrm{kg}$ body weight. We affixed numbered plastic ear-tags (National Band and Tag, Newport, KY), collected blood and tissue samples for genetic analyses, and estimated the age of animals via tooth replacement and wear (Severinghaus 1949). We outfitted 3-year radiocollars (Advanced Telemetry Systems, Isanti, MN) to 192 captured animals. We reversed immobilization with a 12.0-mg intramuscular injection of yohimbine $\left(5 \mathrm{mg} / \mathrm{mL}\right.$, Antagonil ${ }^{\circledR}$; Wildlife Laboratories). All animal-handling procedures were approved by The University of Georgia Institutional Animal Care and Use Committee (permit no. A2002-10119-0). We captured and handled deer under Scientific Collection Permits 43-1999, 16-2000, 2001.008, and 2002.009 from the West Virginia Division of Natural Resources.

We located radiocollared animals $\geq 2$ times/week throughout the 24-hour day from permanent geo-referenced 
telemetry stations, allowing $\geq 10$ hours between telemetry locations. We used 4-element Yagi antennas and radio receivers (Advanced Telemetry Systems) to estimate deer locations. We collected 3-8 preliminary azimuths to pinpoint deer locations and recorded 2 simultaneous azimuths that yielded an angle of $90 \pm 40^{\circ}$. We used the LOCATE function of CALHOME to generate Universal Transverse Mercator coordinates of estimated deer locations (Kie et al. 1996). To estimate telemetry error, we placed radiocollars at random geo-referenced sites in areas commonly used by deer (Samuel and Fuller 1996). Each researcher recorded an azimuth to a radiocollar from 5 telemetry stations. The resulting mean bearing error of $-0.65^{\circ}\left(\mathrm{SD}=8.41^{\circ}\right)$ suggests that telemetry errors caused minimal bias in our telemetry protocol.

\section{Removal-Area Determination}

We selected the removal area based upon its feasibility and suitability for an application of localized management. Laseter (2004) conducted an analysis of telemetry, genetic, and observation data of deer on our study site prior to the initiation of the removal. Based on home ranges and activity centers derived from 20,587 telemetry locations for 127 females and genetic data from 56 of those females, Laseter (2004) determined that the spatial scale of microgeographic variation was approximately $500 \mathrm{~m}$. Additionally, putative social groups were identified on the study site, and verified with genetic and observation data.

We selected one of the social groups identified by Laseter (2004) for removal. We placed the center of the intended removal area in a location central to the social group based on telemetry data. We selected a $1.1-\mathrm{km}^{2}$ circular removal area having a $600-\mathrm{m}$ radius to encompass the targeted animals and to approximate the spatial scale of genetic variation previously determined (Miller 2008). Additionally, 2 forest regeneration sites were within the proposed removal area to evaluate effects of localized management on herbivory.

\section{Initial Removal}

From 7 January to 27 February 2002, we captured deer in modified Clover traps baited with whole kernel corn (Clover 1954). We distributed 14 traps throughout the removal area. We checked traps twice daily and physically restrained trapped deer and gave them an intramuscular injection of $20.0 \mathrm{mg}$ of succinylcholine chloride $\left(20 \mathrm{mg} / \mathrm{mL}\right.$, Anectine ${ }^{\circledR}$; Burroughs Wellcome Co., Research Triangle Park, NC). After recumbency, we immediately euthanized animals by bolt-gun (Cash Special; Accles and Shelvoke Ltd., Birmingham, United Kingdom). Periodic sharp-shooting also was conducted by West Virginia Department of Natural Resources personnel to remove trap-reluctant individuals after 4 weeks of trapping.

We removed lower mandibles from all animals and estimated ages by tooth replacement and wear (Severinghaus 1949). We took all carcasses to the West Virginia Division of Natural Resources Captive Animal Facility and Wildlife Park in French Creek, West Virginia for use in feeding captive carnivores. We recorded person-hours expended during removal and carcass processing activities.

We determined when to cease removal efforts by examining trapping data and conducting deer track-count surveys in the snow. We established a transect that originated $1,800 \mathrm{~m}$ northeast of the center of the removal area, crossed through the removal area, and terminated $1,800 \mathrm{~m}$ southwest from the center of the removal area to detect changes in deer density. We recorded elapsed time since the last snowfall or elapsed time since the last track count. We swept away all tracks after each survey. We conducted 6 track counts before initiating removal, 11 track counts during removal, and 4 track counts after removal. We recorded locations of all tracks that crossed the transect with a submeter Global Positioning System, obtaining $\geq 30$ positions/point. We determined the distance from each track to the center of the removal area using ArcView 3.3.

\section{Monitoring of Radiocollared Deer}

We examined the summer telemetry data (May to Sep) of 30 female deer (1-8+ yr old in 2001) monitored during both pre- and postremoval years (2001 and 2002, respectively) to identify treatment-related movements. We included in our analysis only those deer having preremoval mean distances to the center of the removal area of $<2.5 \mathrm{~km}$. We determined distance from each telemetry location to the center of the removal area using the Animal Movement extension v. 2.04 (Hooge and Eichenlaub 1997) in Arcview GIS 3.3 for deer monitored throughout the summer and recorded in $\geq 25$ locations.

We performed 2 statistical tests to evaluate treatmentrelated movements. We first performed Fisher's distribution-free sign test (Hollander and Wolfe 1973) to test for differences in pre- and postremoval distances from telemetry locations to the center of the removal area. The sign test compared the number of animals with smaller postremoval distances (i.e., moved closer to removal area) with the number of animals with larger postremoval distances (i.e., moved away from removal area). If there is no treatment effect, then the number of animals in each category should be similar. We then performed 2-tailed unequal variance 2sample $t$-tests (Ruxton 2006) on ranked distances for each individual to determine if the mean location distances in the year after treatment application differed from distances prior to treatment application.

Prior to initial removal, we compared distances from telemetry locations to the proposed center of the removal area from the 2 summers prior to application of localized management (2000 and 2001) as previously described for 27 female deer (1-8+ yr old) with mean distances from telemetry locations to the center of the removal area of $<2.5 \mathrm{~km}$. We performed all statistical procedures using SAS (SAS Institute, Cary, NC) and considered results significant if $P<0.05$.

\section{Vegetation Sampling}

To examine effects of the localized removal on browsing rates, we assessed pretreatment deer browsing data in 2001 


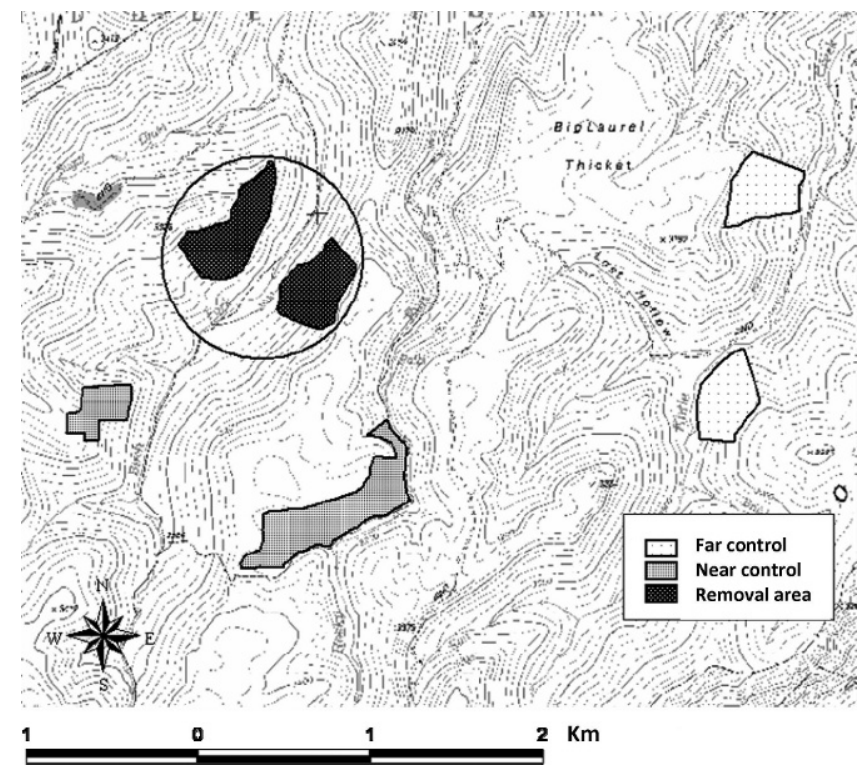

Figure 1. Locations of 6 forest regeneration sites where we measured browsing on the MeadWestvaco Wildlife and Ecosystem Research Forest, Randolph County, West Virginia, USA, from 2001 to 2004. We assigned regeneration sites to 1 of 3 categories (i.e., removal area, near control, and far control) for analysis. The circular area represents the $1.1-\mathrm{km}^{2}$ removal area where we applied the treatment (removal) from 7 January to 27 February 2002.

from 6 regeneration sites each approximately 14 ha in size. Two regeneration sites were located within the removal area, 2 regeneration sites were located $1.1 \mathrm{~km}$ and $1.3 \mathrm{~km}$ from the center of the removal area to serve as near controls, and 2 other regeneration sites located $2.6 \mathrm{~km}$ and $2.7 \mathrm{~km}$ from the center of the removal served as far controls (Fig. 1). We resampled all regeneration sites in 2002, 2003, and 2004 except the far control regeneration sites that we did not resample in 2004. The 2 regeneration sites within the removal area were in their first and third growing seasons during the first year of vegetation sampling. The 2 near control regeneration sites were also in their first and third growing seasons; however, the 2 far control regeneration sites were in their second growing season during the first year of vegetation sampling.

We systematically distributed $30 \quad 1-\mathrm{m}^{2}$ permanently marked sampling plots along the edge of skidder trails throughout each regeneration area. Mean distance between each plot was $121 \mathrm{~m}$. We matched an interior plot to each trail plot $5 \mathrm{~m}$ from the skidder trail in the most perpendicular cardinal direction. We sampled all plots between 15 July and 15 August of each study year. Within each year we sampled plots within \pm 7 days of the original sampling date in 2001 to prevent temporal bias due to changes in vegetation structure, species composition, or herbivory rates.

Within each plot, we recorded total number of browsable units of each species $\leq 1.5 \mathrm{~m}$ from the ground (i.e., available) and total number browsed following Ford et al. (1993). We determined a browsing rate for each sampling plot by dividing number of twig tips browsed by total number available. We assumed all browsing to be caused by white-tailed deer because we detected no browsing by other vertebrates.

We determined the effect of deer removal on changes in browsing rates while accounting for correlation among years by using a repeated-measures multiple analysis of variance in SAS using the generalized linear model procedure. We used a profile analysis procedure to investigate the interaction of time period and treatment by examining parallelism, levels, and flatness of browsing rates between years (von Ende 1993).

We used an analysis of variance where treatment was the main effect to compare browsing rates among treatments within a time period. We performed Tukey's honestly significant difference multiple range test if we detected differences among treatments. We performed a 2-sample $t$ test on data from the final time period to compare herbivory rates between the 2 treatments. We pooled trail and interior plots for analysis. We transformed browsing percentage data using an arcsine square-root transformation (Dowdy et al. 2004).

\section{Second Removal}

We conducted a second removal of deer between 1 January and 21 February 2005, 3 years after the initial removal. We implemented the second removal to compare the number of animals captured and effort required with the initial removal. Additionally, we collected blood and tissue samples for genetic comparison with individuals captured in the initial removal. We utilized the same trapping methods and duration as the initial removal. We also recorded personhours expended collecting biological information from carcasses and cleaning of processing facilities.

\section{RESULTS}

\section{Initial Removal}

We removed 51 deer ranging in age from 0.5 year to $8.5+$ years from the $1.1-\mathrm{km}^{2}$ targeted area during the 8 -week period. Number of individuals removed per week was negatively related to duration of trapping (Fig. 2). Females comprised most animals (39 of 51), with a mean ( \pm SE) age of $3.7 \pm 0.4$ years. Mean age was lower for males (0.9 \pm $0.3 \mathrm{yr}$ old) because most males were fawns (9 of 12). Male ages ranged from 0.5 year to 3.5 years old.

Results from our track counts conducted before, during, and after removal indicated a negative relationship between number of deer tracks and duration of trapping. Mean number of tracks recorded within the removal area was 22.2 \pm 7.0 tracks $/ 10$ hours during the preremoval period. The number decreased to $5.6 \pm 1.2$ tracks/10 hours during removal and $2.5 \pm 1.5$ tracks/10 hours postremoval. We removed 8 of the 9 radiocollared females with home ranges encompassing a portion of the removal area. We captured no radiocollared deer having home ranges outside of the removal area.

For the initial removal, 467 person-hours were required. Preparing trap sites and prebaiting required 24.7 personhours. Most effort was expended checking traps, removing trapped animals, and sharp-shooting. These activities 


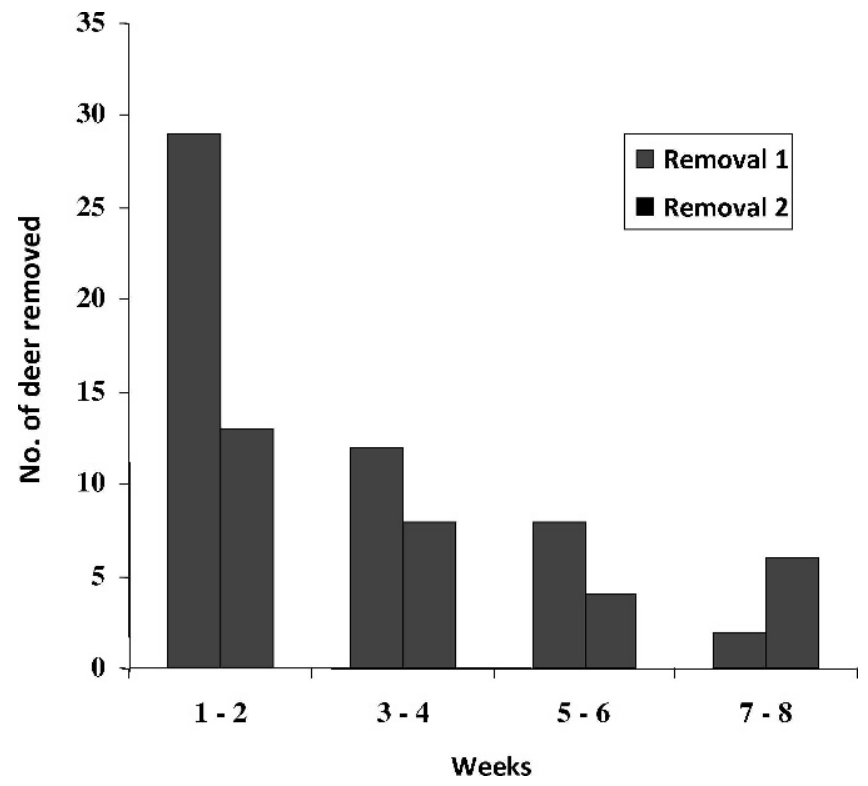

Figure 2. Number of white-tailed deer we removed from a $1.1-\mathrm{km}^{2}$ experimental removal area from 7 January to 27 February 2002 (removal 1) and 1 January to 21 February 2005 (removal 2) on the MeadWestvaco Wildlife and Ecosystem Research Forest, Randolph County, West Virginia, USA.

required 442.5 person-hours, almost $95 \%$ of the total person-hours expended. A mean effort of 9.2 personhours/deer removed was required.

\section{Monitoring of Radiocollared Deer}

Excluding the single radiocollared female that we did not remove, we recorded 6,630 telemetry locations from 84 extant radiocollared deer ( $1 \mathrm{M}$ and $83 \mathrm{~F}$ ) each having $\geq 34$ locations from 18 February 2002 to 20 December 2002 (Fig. 3). Mean distance from all telemetry locations to the center of the removal area was $2,607.3 \pm 10.2 \mathrm{~m}$ (range $=$ $96.4-5,433.8 \mathrm{~m}$ ). There were 11 telemetry locations within the removal area from 10 different deer. The proportion of each animal's telemetry points that occurred within the removal area averaged $1.4 \pm 0.04 \%$ (range $=1.1-2.4 \%$ ) of all telemetry points.

Mean number of telemetry locations for deer in the preremoval and postremoval periods was $29.3 \pm 0.3$ (range $=26-32$ ) and $38.5 \pm 0.6$ (range $=28-44$ ), respectively. Of the 30 female deer having mean distances from telemetry locations to the center of the removal area of $<2.5 \mathrm{~km}, 19$ (63.3\%) had smaller distances in the summer following removal treatment. Results of the sign test comparing deer with smaller postremoval distances to those with larger postremoval distances approached statistical significance $(z$ $=1.46, P=0.072)$.

We detected differences between preremoval and postremoval distances to the center of the removal area by $t$-tests in 8 of 30 (26.7\%) deer (Fig. 4). All significant differences in distances to the removal area were of deer moving closer to the removal area; we detected no significant movements away from the removal area. The mean difference in preand postremoval distances of the 8 animals was $136.3 \pm$

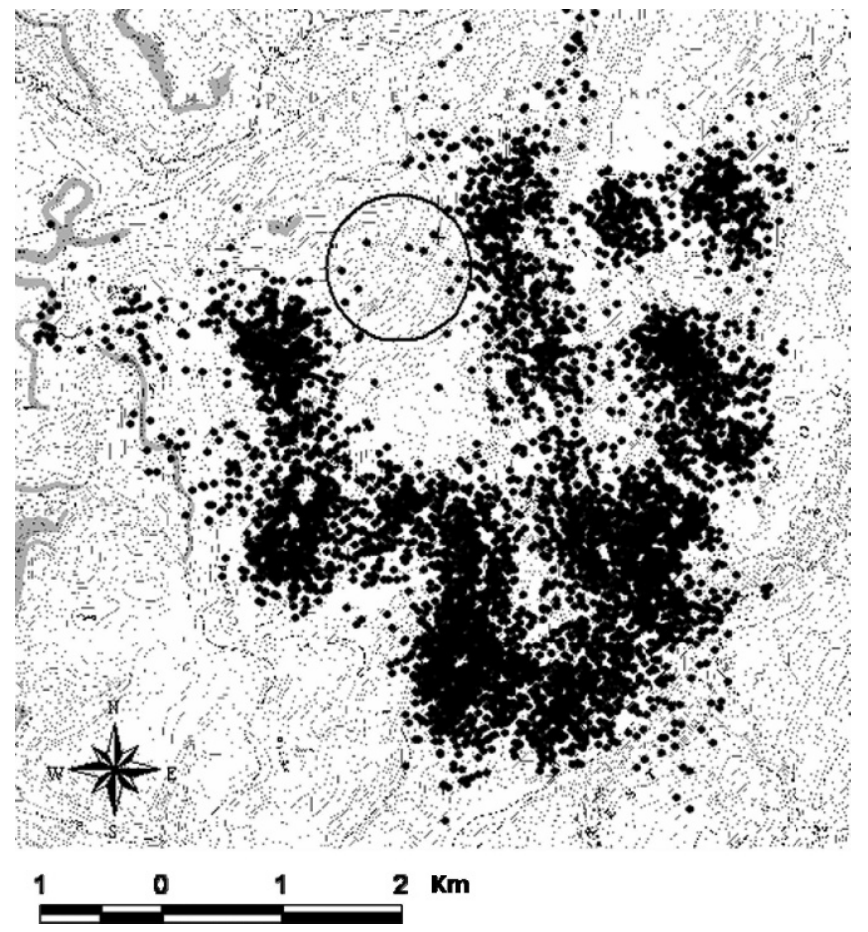

Figure 3. Telemetry locations from 18 February 2002 to 20 December 2002 of 84 extant radiocollared deer $(1 \mathrm{M}$ and $83 \mathrm{~F})$ after application of localized management on the MeadWestvaco Wildlife and Ecosystem Research Forest, Randolph County, West Virginia, USA. The circular area represents the $1.1-\mathrm{km}^{2}$ removal area where we applied the treatment.

$13.2 \mathrm{~m}$ (range $=57.7-171.1 \mathrm{~m})$ closer to the center of the removal area.

Mean number of telemetry locations collected from deer in the 2 summers prior to application of localized management

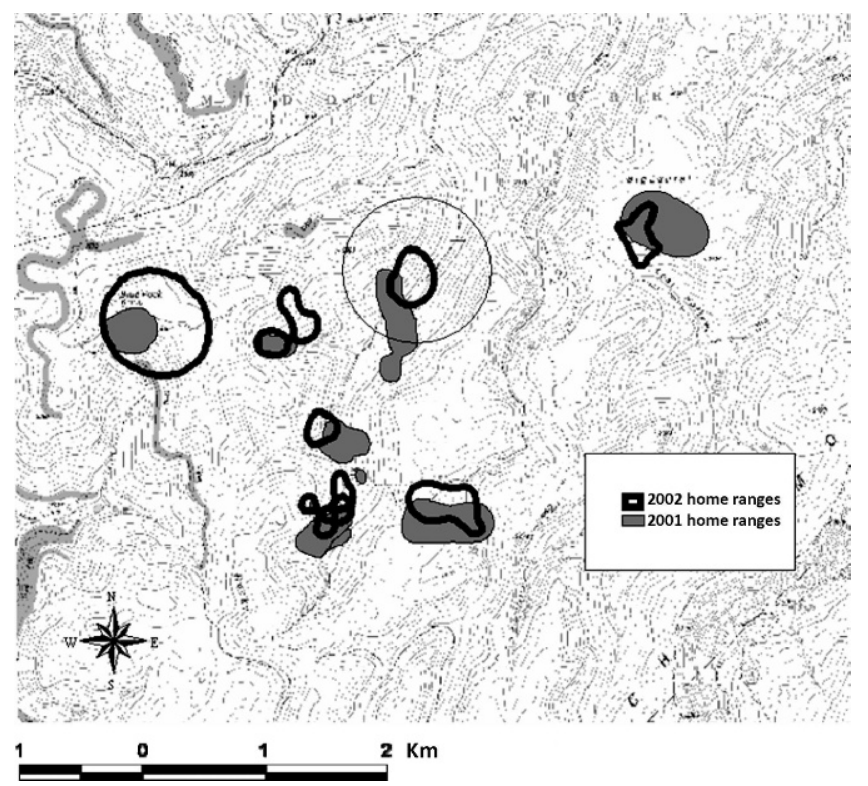

Figure 4. The pre- and postremoval (2001 and 2002, respectively) summer home ranges ( $50 \%$ fixed kernel) of 8 adult female deer with significant home range shifts toward the removal after application of localized management on the MeadWestvaco Wildlife and Ecosystem Research Forest, Randolph County, West Virginia, USA. The circular area represents the $1.1-\mathrm{km}^{2}$ removal area where we applied the treatment. 


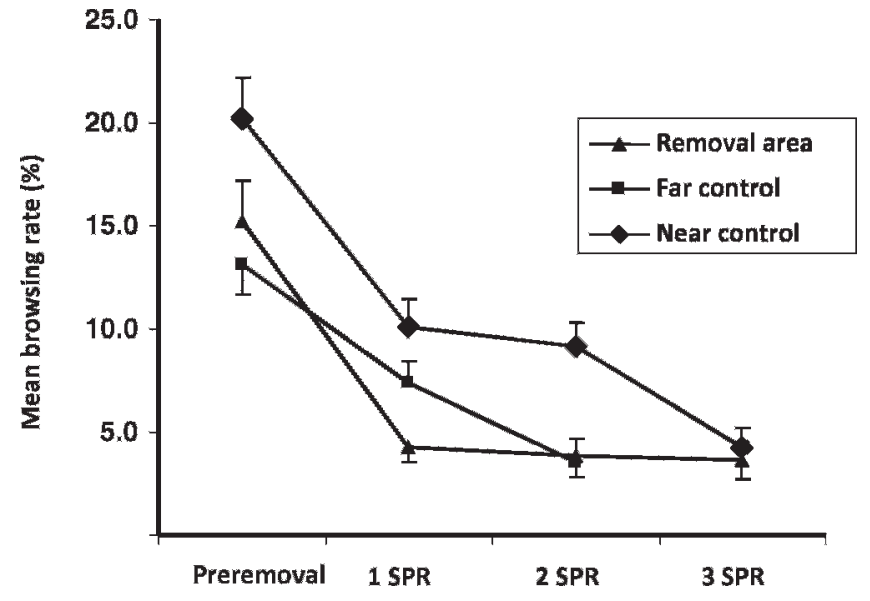

Figure 5. Browsing rates of regeneration sites preremoval and 1-3 summers postremoval (SPR) of deer on the MeadWestvaco Wildlife and Ecosystem Research Forest, Randolph County, West Virginia, USA, from 2001 to 2004. We assigned regeneration sites $(n=6)$ to 1 of 3 categories (i.e., removal area, near control, and far control) for analysis.

(2000 and 2001) was $65.0 \pm 0.4$ (range $=59-69)$ and 29.4 \pm 0.3 (range $=25-32$ ), respectively. The sign test detected no differences between distances from telemetry locations to the center of the proposed removal area for the 2 summers $(z=0.96, P=0.17)$. Differences in distances were detected by $t$-tests in 5 of $27(18.5 \%)$ deer. Of those 5 animals, 4 moved closer to the removal area and one moved farther away. The mean difference in pre- and postremoval distances of deer moving closer and moving farther away was $132.6 \pm 9.8 \mathrm{~m}$ (range $=103.8-148.0 \mathrm{~m})$ and $99.5 \mathrm{~m}$, respectively.

\section{Herbivory Data}

We recorded browsable units from 38 woody and 4 semiwoody plant species. However, 12 species constituted $85.0 \%$ of available browsable units $(187,560$ of 220,631$)$ recorded in our study. These included species representative of the woody overstory present prior to timber harvesting such as black cherry, red maple, sugar maple, birch, magnolia (Magnolia fraseri and $M$. acuminata), American beech, yellow-poplar, northern red oak, and witch-hazel (Hamamelis virginiana). Three early successional invaders: fire cherry (Prunus pensylvanica), striped maple (Acer pensylvanicum), and blackberry (Rubus spp.), increased in abundance following timber harvesting.

Browsing rates for all woody and semi-woody species combined decreased annually among the 3 treatments (Fig. 5). Browsing rates in the removal area, near control, and far control decreased $71.7 \%, 50.0 \%$, and $43.5 \%$ from the preremoval summer to the first summer postremoval, respectively. The rate of decrease did not differ among treatments $\left(F_{2,335}=2.31, P=0.10\right)$.

During the second summer postremoval, the browsing rate of the far control decreased an additional $51.4 \%$ from a mean browsing rate of $7.4 \pm 1.0 \%(n=118)$ to $3.6 \pm 0.8 \%$ $(n=120)$. During the same time period browsing rates of the near control and removal area decreased $9.9 \%$ and $9.3 \%$, respectively. The rate of decrease differed among the 3 treatments $\left(F_{2,335}=8.35, P<0.001\right)$. However, mean browsing rate of the far control $(3.6 \pm 0.8 \%, n=120) \mathrm{did}$ not differ from the browsing rate of the removal area $(3.9 \pm$ $0.8 \%, n=119)$ in the second summer postremoval $\left(F_{2,358}=\right.$ 18.06, $P<0.001$ ).

During the third summer postremoval, browsing rates further decreased $52.7 \%$ and $5.1 \%$ for the near control and removal area, respectively. The rate of decrease differed between the 2 treatments $\left(F_{1,236}=14.60, P<0.001\right)$. Mean browsing rate did not differ between the near control $(4.3 \pm 0.9 \%, n=120)$ and the removal area $(3.7 \pm 1.0 \%, n$ $=118)$ in the third summer postremoval $\left(t_{236}=1.35, P=\right.$ $0.18)$.

\section{Second Removal}

Three years after the initial treatment, we removed an additional 31 deer from the original removal area using the same techniques as the initial removal. The number of deer removed per week declined as the duration of trapping increased (Fig. 2). Females comprised most of the animals removed (26 of 31). Mean age of females was $4.5 \pm 0.5$ years (range $=0.5-8.5+y r)$. Eighteen females were $\geq 3.5$ years of age. All 5 males removed were fawns $(0.5 \mathrm{yr})$.

We expended 372.4 person-hours during the second removal period. Preparing trap sites and prebaiting required 6.9 person-hours. Checking traps, removing trapped animals, and sharp-shooting efforts required 365.5 personhours. A mean effort of 12.0 person-hours/deer removed was required. Collecting biological data from carcasses and cleaning of processing facilities and equipment required an additional 2.4 person-hours/deer.

\section{DISCUSSION}

Based on trapping success, track-count data, and removal of radiocollared individuals, we estimate that we removed $>80 \%$ of resident animals within the 8 -week removal period. Campbell et al. (2006) found that 89.5\% (34 of 38) of radiocollared deer utilized bait stations occurring within their home range during a 14-16-day observation period on the same area. We distributed Clover traps in our removal area at a density of 1 trap/8.1 ha. Although visitation to bait stations may not be equivocal to deer use of Clover traps, we believe that placing multiple traps within the home range of each target animal greatly increased our removal success. Thus, our results demonstrate that a large proportion of deer in a high-density population can be removed from a $1.1-\mathrm{km}^{2}$ removal area by the combination of trapping and sharpshooting.

McNulty et al. (1997) reported that 14 of 17 animals from a known social group were successfully removed from a 1.4$\mathrm{km}^{2}$ area in the Adirondacks of New York. They calculated their removal-area size retrospectively based on home range analysis of the targeted deer. Prior knowledge of social structuring and movement data typically are not available, although this may not be necessary if deer exhibit high site fidelity and minimal female dispersal (McNulty et al. 1997). In the years following the application of localized management in the Adirondack Mountains, deer density declined to 
an area-wide estimate of $2 \mathrm{deer} / \mathrm{km}^{2}$ because of severe winter weather (Oyer and Porter 2004). Oyer and Porter (2004) reported that the reduced deer density persisted in the $1.4-\mathrm{km}^{2}$ treatment area for approximately 5 years. Furthermore, Oyer and Porter (2004) concluded that all deer captured in their removal area were individuals missed during removal efforts or descendants of those deer. The low initial deer density, and subsequent additional decrease in deer density, of the Adirondack study are important differences between our study and that of Oyer and Porter (2004). Population density in the Adirondack study was estimated to be $6 \mathrm{deer} / \mathrm{km}^{2}$ at the time of removal (McNulty et al. 1997), whereas we observed $12-20$ deer $/ \mathrm{km}^{2}$ (Langdon 2001). Our removal of 51 deer from the $1.1-\mathrm{km}^{2}$ treatment area compared to the removal of 14 deer from a $1.4-\mathrm{km}^{2}$ treatment area in the Adirondack site is consistent with density estimates on our area being $\geq 3$ times that of the New York study site.

The high densities we observed have substantial implications for the persistence of a population void. If initial deer densities in an area are low prior to an application of localized management, then few missed individuals will be left as population founders. However, in sites with high deer densities where human-deer conflicts often occur, and herd management is needed, even the most intense removal efforts may leave a sizable founding population.

Dispersal rates of juvenile females are critical to the effectiveness of the localized management technique (Porter et al. 2004). Localized management assumes that population density has little effect on female dispersal rates (Porter et al. 1991, McNulty et al. 1997). However, because of the high population density on our study area, there may be an increased chance of colonizing voids by female dispersal based on the high number of deer surrounding the removal area. Furthermore low female dispersal should not be assumed for all areas. High female dispersal rates have been reported in areas with heavy annual harvests and a young female age structure (Comer et al. 2005), as well as in fragmented agricultural landscapes (Nixon et al. 1991).

Site fidelity of adjacent adult females also is a critical component to the persistence of a population void. In the Adirondacks, no movements of adjacent animals were detected (Oyer and Porter 2004). We detected no immigration of adjacent animals in our study. However, no radiocollared animals with pretreatment mean telemetry locations $<1 \mathrm{~km}$ from the center of the removal area survived removal efforts, with the exception of one missed adult female. Undoubtedly our lack of immediately adjacent radiocollared deer is responsible for not detecting immigration of surviving individuals. Based on our telemetry data, 8 of $30(26.7 \%)$ adult females having pretreatment mean telemetry locations $<2.5 \mathrm{~km}$ from the center of the removal area were significantly closer to the removal area and none had mean telemetry locations significantly further away from the removal area after the application of localized management. Therefore, we conclude that some shift of home ranges occurred in response to the population void.
Our results suggest that encroachment from adjacent animals or dispersal into the removal area may reduce the persistence of removal effects in high-density deer herds. Except for the single radiocollared adult female missed during the initial application of localized management, it is unknown how many deer were left as founding individuals. However, the declines in removal rates over the trapping period, track counts conducted before, during, and after the removal, and our success in removing 8 of 9 radiocollared animals within the removal area indicates that our initial removal was successful. Comparisons of the genetic relatedness of deer removed during the initial removal with deer collected during the second removal found evidence of population differentiation based on significant Wright's $F_{\text {st }}$, Wright's $\mathrm{F}_{\mathrm{is}}$, and Hardy-Weinberg disequilibrium tests (Miller 2008). Thus, repopulating deer were not individuals that survived the initial removal, but rather unrelated animals with dissimilar genetic characteristics. Of the 31 deer we removed 3 years later, 18 of them were alive at the time of initial removal based on their estimated age. Their presence in the removal area is likely the result of some combination of dispersal into the area or shift from adjacent areas.

Based on the large number of deer removed 3 years after the initial removal, localized management provided, at best, only a short-term reduction in deer densities. Although we removed 31 individuals within an 8-week trapping period, there were additional deer in the removal area after the conclusion of the second application of localized management. Approximately 3 weeks after the cessation of removal efforts, West Virginia Department of Natural Resources personnel observed $\geq 4$ deer within the removal area and collected an additional 2.5-year-old female. Therefore $\geq 35$ animals resided in the removal area 3 years after the initial removal of 51 animals.

In the first summer after treatment we observed the greatest decline in browsing rates on the removal area, although the rate of decline was not statistically different from the other areas. Although deer removal may have reduced browsing pressure in the removal area during the first year, browsing rates of the far control and near control areas also declined in the following summers until their browsing rates did not differ from those within the removal area. Over the study period, the proportion of the study area composed of harvested areas $<10$ years old increased from $8 \%$ to $14 \%$. Concurrently, indices of deer abundance indicated that the area-wide population remained stable (Miller et al. 2009). Theoretically, increasing ecological carrying capacity by providing abundant forage across a landscape can reduce overall browsing pressure (Tilghman and Marquis 1989, Marquis et al. 1992, Ford et al. 1993, Kalen 2005). We believe this increase in natural forage was responsible for the declines in browsing rates observed for all of the removal and control areas. We conclude that although localized management may have provided a temporary reduction in browsing rates, increasing forage availability may be a more effective means of minimizing the impact of deer browsing on forest regeneration areas. 


\section{MANAGEMENT IMPLICATIONS}

We found that the combination of trapping and periodic sharp-shooting was effective for removing deer from a heavily forested remote area. However, our data suggest that one application of localized management in high-density deer herds may only provide temporary reductions of deer densities despite appearing to fulfill all a priori requirements for localized management. Repeated removals (e.g., every $2 \mathrm{yr}$ ) or substantially increasing sizes of removal areas may be necessary to counter impacts of encroachment, dispersal, and reproduction of unharvested individuals in high-density deer populations.

\section{ACKNOWLEDGMENTS}

Financial assistance was provided by the MeadWestvaco Corporation, the West Virginia Division of Natural Resources, and the United States Department of Agriculture National Research Initiative Competitive Grants Program (grants 00-35101-9284 and 03-35101-13719). We thank D. A. Osborn, J. L. Crum, and P. D. Keyser for logistical assistance. We also thank the technicians and volunteers who provided valuable field assistance. Comments from J. P. Carroll, C. J. Nairn, and R. J. Warren improved this manuscript.

\section{LITERATURE CITED}

Adams, J. P. 2005. Home range and behavior of the timber rattlesnake (Crotalus horridus). Thesis, Marshall University, Huntington, West Virginia, USA.

Beringer, J., L. P. Hansen, J. A. Demand, J. Sartwell, M. Wallendorf, and R. Mange. 2002. Efficacy of translocation to control urban deer in Missouri: costs, efficiency, and outcome. Wildlife Society Bulletin 30:767-774.

Campbell, T. A. 2003. Movement ecology of white-tailed deer in the central Appalachians of West Virginia. Dissertation, University of Georgia, Athens, USA.

Campbell, T. A., C. A. Langdon, B. R. Laseter, W. M. Ford, J. W. Edwards, and K. V. Miller. 2006. Movements of female white-tailed deer to bait sites in West Virginia, USA. Wildlife Research 33:1-4.

Campbell, T. A., B. R. Laseter, W. M. Ford, and K. V. Miller. 2004. Feasibility of localized management to control white-tailed deer in forest regeneration areas. Wildlife Society Bulletin 32:1124-1131.

Campbell, T. A., B. R. Laseter, W. M. Ford, and K. V. Miller. 2005. Population characteristics of a central Appalachian white-tailed deer herd. Wildlife Society Bulletin 33:212-221.

Clarkston, R. B. 1993. Destruction of the upland forest by lumbering and fire. Pages 35-46 in S. L. Stephenson, editor. Upland forest of West Virginia. McClain, Parsons, West Virginia, USA.

Clover, M. R. 1954. A portable deer trap and catch-net. California Fish and Game 40:367-373.

Comer, C. E., J. C. Kilgo, G. J. D’Angelo, T. G. Glenn, and K. V. Miller. 2005. Fine-scale genetic structure and social organization in female white-tailed deer. Journal of Wildlife Management 69:332-344.

Conover, M. R. 1997. Monetary and intangible valuation of deer in the United States. Wildlife Society Bulletin 25:298-305.

Côté, S. D., T. P. Rooney, J. P. Tremblay, C. Dussault, and D. M. Waller. 2004. Ecological impacts of deer overabundance. Annual Review of Ecology, Evolution, and Systematics 35:113-147.

Dowdy, S., S. Weardon, and D. Chilko. 2004. Statistics for research. Third edition. John Wiley and Sons, Hoboken, New Jersey, USA.

Ford, W. M., A. S. Johnson, P. E. Hale, and J. M. Wentworth. 1993. Availability and use of spring and summer woody browse by deer in clearcut and uncut forests of the southern Appalachians. Southern Journal of Applied Forestry 17:116-119.
Hawkins, R. E., L. D. Martoglio, and G. G. Montgomery. 1968. Cannonnetting deer. Journal of Wildlife Management 32:191-195.

Hirth, D. H. 1977. Social behavior of white-tailed deer in relation to habitat. Wildlife Monographs 53.

Hollander, J., and D. A. Wolfe. 1973. Non-parametric statistical methods. John Wiley and Sons, New York, New York, USA.

Hooge, P. N., and B. Eichenlaub. 1997. Animal movement extension to ARCVIEW. Version 1.1. U.S. Geological Survey, Anchorage, Alaska, USA.

Horsley, S. B., and D. A. Marquis. 1983. Interference by weeds and deer with Allegheny hardwood reproduction. Canadian Journal of Forest Resources 13:61-69.

Horsley, S. B, S. L. Stout, and D. S. deCalesta. 2003. White-tailed deer impact on the vegetation dynamics in northern hardwood forest. Ecological Applications 13:98-118.

Kalen, C. 2005. Deer browsing and impact on forest development. Journal of Sustainable Forestry 21:51-62.

Kie, J. G., J. A. Baldwin, and C. J. Evans. 1996. CALHOME: a program for estimating animal home ranges. Wildlife Society Bulletin 24:342-344.

Kilpatrick, H. J., S. M. Spohr, and K. K. Lima. 2001. Effects of population reduction on home ranges of female white-tailed deer at high densities. Canadian Journal of Zoology 79:949-954.

Langdon, C. A. 2001. A comparison of white-tailed deer population estimation methods in West Virginia. Thesis, West Virginia University, Morgantown, USA.

Laseter, B. R. 2004. Socio-spatial characteristics and genetic structure of white-tailed deer in the central Appalachians of West Virginia. Dissertation, University of Georgia, Athens, USA.

Marquis, D. A. 1974. The impact of deer browsing on Allegheny hardwood regeneration. U.S. Department of Agriculture, Forest Service, Research Paper NE-308, Upper Darby, Pennsylvania, USA.

Marquis, D. A. 1981. The effect of deer browsing on timber production in Allegheny hardwood forests of northwestern Pennsylvania. U.S. Department of Agriculture, Forest Service, Research Paper NE-475, Broomall, Pennsylvania, USA.

Marquis, D. A., R. L. Ernst, and S. L. Stout. 1992. Prescribing silvicultural treatments in hardwood stands of the Alleghenies (revised). U.S. Department of Agriculture, Forest Service, General Technical Report NE-96, Radnor, Pennsylvania, USA.

Mathews, N. E. 1989. Social structure, genetic structure, and anti-predator behavior of white-tailed deer in the Central Adirondacks. Dissertation, State University of New York, Syracuse, USA.

Mathews, N. E., and W. F. Porter. 1993. Effect of social structure on genetic structure of free-ranging white-tailed deer in the Adirondack Mountains. Journal of Mammalogy 74:33-43.

McNulty, S. A., W. F. Porter, N. E. Mathews, and J. A. Hill. 1997. Localized management for reducing white-tailed deer populations. Wildlife Society Bulletin 25:265-271.

McShea, W. J., and J. H. Rappole. 1997a. Herbivores and the ecology of forest understory birds. Pages 298-309 in W. J. McShea, H. B. Underwood, and J. H. Rappole, editors. The science of overabundance: deer ecology and population management. Smithsonian Institution, Washington, D.C., USA.

McShea, W. J., and J. H. Rappole. 1997b. The science and politics of managing deer within a protected area. Wildlife Society Bulletin 25:443446.

McShea, W. J., and J. H. Rappole. 2000. Managing the abundance and diversity of breeding bird populations through manipulation of deer populations. Conservation Biology 14:1161-1170.

McWilliams, W. H., S. L. Stout, T. W. Bowersox, and L. H. McCormick. 1995. Adequacy of advance tree-seedling regeneration in Pennsylvania's forests. Northern Journal of Applied Forestry 12:187-191.

Merrill, J. A., E. G. Cooch, and P. D. Curtis. 2006. Managing an overabundant deer population by sterilization: effects of immigration, stochasticity, and the capture process. Journal of Wildlife Management 70:268-277.

Miller, B. F. 2008. Social structuring of a central Appalachian deer herd and a test of localized management. Dissertation, The University of Georgia, Athens, USA.

Miller, B. F., T. A. Campbell, B. R. Laseter, W. M. Ford, and K. V. Miller. 2009. White-tailed deer herbivory and timber harvesting rates: implications for regeneration success. Forest Ecology and Management 258:1067-1072. 
Miller, K. V. 1997. Considering social behavior in the management of overabundant white-tailed deer populations. Wildlife Society Bulletin 25:279-281.

Nixon, C. M., L. P. Hansen, P. A. Brewer, and J. E. Chelsvig. 1991. Ecology of white-tailed deer in an intensively farmed region of Illinois. Wildlife Monographs 118.

Oyer, A. M., and W. F. Porter. 2004. Localized management of whitetailed deer in the central Adirondack Mountains, New York. Journal of Wildlife Management 68:257-265.

Porter, W. F., N. E. Mathews, H. B. Underwood, R. W. Sage, and D. F. Behrend. 1991. Social organization in deer: implications for localized management. Environmental Management 15:809-814.

Porter, W. F., H. B. Underwood, and J. L. Woodard. 2004. Movement behavior, dispersal, and the potential for localized management of deer in a suburban environment. Journal of Wildlife Management 68:247-256.

Ruxton, G. D. 2006. The unequal variance $t$-test is an underused alternative to the Student's $t$-test and the Mann-Whitney U-test. Behavioral Ecology 17:688-690.

Samuel, M. D., and M. R. Fuller. 1996. Radiotelemetry. Pages 370-418 in T. A. Bookhout, editor. Research and management techniques for wildlife and habitats. Fifth edition, revised. The Wildlife Society, Bethesda, Maryland, USA.

Schuler, T. M., W. M. Ford, and R. J. Collins. 2002. Successional dynamics and restoration of a montane coniferous forest in the central Appalachians, USA. Natural Areas Journal 22:88-98.

Severinghaus, C. A. 1949. Tooth development and wear as criteria of age in white-tailed deer. Journal of Wildlife Management 13:195-216.
Stout, R. J., B. A. Knuth, and P. D. Curtis. 1997. Preferences of suburban landowners for deer management techniques: a step towards better communication. Wildlife Society Bulletin 25:348-359.

Strausbaugh, P. D., and E. L. Core. 1977. Flora of West Virginia. Seneca, Gainsville, West Virginia, USA.

Tierson, W. C., G. F. Mattfeld, R. W. Sage, Jr., and D. F. Behrend. 1985. Seasonal movements and home ranges of white-tailed deer in the Adirondacks. Journal of Wildlife Management 49:760-769.

Tilghman, N. G. 1989. Impacts of white-tailed deer on forest regeneration in northwestern Pennsylvania. Journal of Wildlife Management 53:524532.

Tilghman, N. G., and D. A. Marquis. 1989. Deer damage in central hardwoods: a potential problem. Pages 1-3 in F. B. Clark, technical editor and J. G. Hutchinson, editor. Central hardwood notes. U.S. Department of Agriculture, Forest Service, North Central Forest Experiment Station, Note 8.01, St. Paul, Minnesota, USA.

von Ende, C. N. 1993. Repeated-measures analysis: growth and other time dependent measures. Pages 113-137 in S. M. Scheiner and J. Gurevitch, editors. Design and analysis of ecological experiments. Chapman and Hall, New York, New York, USA.

Waller, D. M., and W. S. Alverson. 1997. The white-tailed deer: a keystone herbivore. Wildlife Society Bulletin 25:217-225.

Warren, R. J. 1991. Ecological justification for controlling deer populations in eastern national parks. Transactions of the North American Wildlife and Natural Resources Conference 56:56-66.

Associate Editor: Euler. 